\title{
AS FONTES FILOSÓFICAS DA PROBLEMÁTICA EDUCACIONAL: IMPLICAÇÕES PARA A FORMAÇÃO E A EMANCIPAÇÃO HUMANA
}

Luciana Pedrosa Marcass*

Resumo: O objetivo deste texto é abordar as concepções de formação humana existentes ao longo da história da humanidade de modo a apresentar, em linhas gerais, como as principais correntes filosóficas explicam como ocorre o processo de humanização do homem. Entre as fontes apresentadas, entende-se que a filosofia da práxis é aquela que melhor responde à problemática educacional atual, na medida em que explica como o homem aprende, educa e produz conhecimento a partir do trabalho como atividade fundante do ser social.

Palavras-chave: Educação, filosofia, emancipação humana.

Abstract: The objective of this text is to address the conceptions of human formation in existence throughout the history of mankind in order to present, in general terms, as the main philosophical currents explain how the process of humanization of man. Among the sources presented, it is understood that the philosophy of praxis is the one that best responds to the current educational problem, in that it explains how humans learn, educate and produces knowledge from the work as the founding of social activity

Keywords: Education, philosophy, human emancipation. 


\section{Introdução}

Em virtude da abrangência e profundidade da reflexão proposta para este texto, qual seja, as fontes filosóficas da problemática educacional, bem como da diversidade de autores e abordagens possíveis sobre este assunto, minha opção foi tratar, em linhas gerais, o pensamento de alguns autores clássicos da filosofia quanto ao tema da formação humana, que se constituem como importantes fontes de reflexão para a filosofia da educação: Platão, Coménio, Kant, Rousseau, Locke, Nietzsche, Marx e Engels. Em seguida, procuro construir uma leitura de conjunto, articulando essas fontes com as correntes ou tradições da filosofia e da pedagogia. Por fim, busco analisar como podemos conceber a formação humana a partir da herança deixada por Marx e Engels, sugerindo que a filosofia da práxis é a única capaz de apanhar a problemática educacional em sua totalidade, uma vez que a localiza na história, identifica suas contradições e considera suas mediações fundamentais com a esfera do trabalho, do poder e da cultura.

\section{1) O idealismo platônico}

Uma primeira fonte de reflexões sobre o problema da educação ou da formação humana deriva da antiguidade clássica e encontra em Platão (345 a. C.) a sua principal referência. Como se sabe, para Platão, a realidade era composta de duas esferas diferentes: o Mundo das Idéias e o Mundo das Sombras, ou ainda, o Mundo da Essência e o Mundo da Aparência. O mundo das idéias era o mundo verdadeiro, lugar da essência relativa a tudo que diz respeito ao homem e à vida, portanto, perfeito, imutável, universal, perene, uno e real. Já o mundo das sombras era o mundo empírico, um mundo de aparências, lugar das coisas sensíveis e imperfeitas, mutáveis, singulares, 
inconstantes, contingentes, múltiplas, irreais, portanto, falsas.

Quanto ao próprio homem, a mesma divisão se impõe, sendo este um ser que, manifestando-se através do corpo, do desejo, dos sentidos, dos hábitos, da vontade e das condutas morais, habita o mundo das sombras. Nele, o que pertence ao mundo magnífico das idéias é o espírito em sua forma pensante. Daí a clássica concepção de homem, bem conhecida entre nós, como uma dualidade entre carne e espírito, ou entre corpo e alma.

Esta visão conduziu, no mundo antigo, a pedagogia a descurar de tudo o que era empírico e sensível no homem e a conceber a educação como um conjunto de medidas para desenvolver no homem sua capacidade de participação na realidade ideal (no mundo das ideias), isto é, tudo o que define e atinge a sua essência verdadeira, embora asfixiada pela existência empírica. A filosofia platônica tematizou também, segundo Nunes (1989) a educação e as possibilidades de educar o homem para a vida na polis, conforme as regras derivadas de sua natureza racional e política.

Entretanto, pregando um idealismo absoluto, posto que desacreditava na justiça da Pólis, Platão estabelece que a República é uma utopia e a polis deve ser governada pelas elites pensantes, os chamados governantes-filósofos, ou soberanos que se tornam filósofos. Por isso, a educação aí assume a função de criação e atualização das idéias perfeitas através do ensino e do aprimoramento das virtudes e da prática da contemplação.

Para este autor, à educação cabia conduzir o homem à descoberta da Pátria verdadeira e ideal por meio da educação do pensamento e do aprimoramento do espírito em sua forma pensante. Para isso, deveria recorrer à observação sensível das coisas e ao estudo dialético das opiniões, tendo como finalidade vencer as sensações e opiniões consideradas falsas, contraditórias, equívocas, imperfeitas, em busca do conceito, da essência, da verdade absoluta e incontestável. O que se desejava 
era encontrar o fundamento, alcançando a idéia perfeita do bem, do belo, da verdade, da justiça, da coragem, da amizade, da prudência, do amor, da temperança, idéias e valores que deveriam ser apreendidos por meio do exercício da filosofia, da retórica, da argumentação, da persuasão, do bem falar em público ${ }^{1}$, da astúcia e do debate, embora o conhecimento verdadeiro não estivesse ao alcance dos homens e do mundo sensível. "O conhecimento do mundo imutável da idéia só é possível como reminiscência da vida que o pensamento observou nesse mundo, antes de animar o corpo e de surgir entre os reflexos das coisas" (Suchodolski, 1984, p. 19).

De modo idêntico, a educação moral deveria interferir sobre os desejos, os hábitos, a vontade, mas as decisões definitivas sobre o bem e o mal provinham do mundo ideal, a que pertence o pensamento.

Por isso, de uma forma geral, é possível dizer que a Paidéia Platônica-o seu ideal de formação humana - tem como principal preocupação a definição e a busca, por meio da reflexão e do desenvolvimento do pensamento (filosofia), de virtudes morais e políticas capazes de sustentar o projeto utópico da República. Toda a aposta de Platão sobre a estruturação do novo Estado - a República - está baseada na educação, seja aquela voltada aos guardiões, onde a força, a beleza e a vontade são moldadas pela educação física - a ginástica para o corpo, música para a alma, diria o filósofo - seja aquela voltada aos governantes, cuja formação deveria se assentar na razão, na sabedoria, portanto, na filosofia.

(...) só pela educação (isto é, pela formação do homem) se pode atingir o fim visado pelo legislador e, quando aquela é verdadeiramente eficaz, dispensa as leis. Esta - a educação - liberta o Estado da necessidade de estar constantemente criando e modificando leis... 
e torna inúteis as normas especiais sobre a polícia, mercado e postos, sobre o comércio, as ofensas e as violências, assim como sobre o processo civil e o regime da justiça (JAEGER, 2001, p. 805-806).

Embora Platão não tenha dedicado um diálogo específico ao tema da educação, este atravessa o conjunto de sua obra, e é um elemento central de toda a sua teoria do conhecimento, da moral e da política. O legado deixado pela concepção grega de formação humana inspirou toda uma tradição que se seguiu nos períodos posteriores.

Foi assim que o cristianismo manteve, transformou e desenvolveu a concepção platônica, acentuando ainda mais a oposição entre essas duas esferas da realidade: a verdadeira e eterna, de um lado, a aparente e temporal de outro. Realçou o conflito interior do homem entre o que o liga à vida material (corpo) e o que o une ao mundo espiritual (alma/espírito). A teoria do pecado original é uma advertência para que o homem não se deixe levar pelas aparências das coisas, cedendo aos galanteios luxuriosos do meio que o rodeia, sob pena de se corromper e de se exilar de sua verdadeira essência: o criador.

Mas para isso, não basta que a educação se negue a apoiarse nessa realidade: é preciso vencê-la. Portanto, à verdadeira educação cumpre ligar o homem à sua verdadeira pátria, a pátria celeste e destruir tudo o que prende o homem à sua existência terrestre. Para toda a tradição católico-tomista ${ }^{2}$, o ensino foi concebido como uma atividade em virtude da qual os dons potenciais se tornam realidade atual. Portanto, a formação humana é um processo cujo elemento mobilizador é a vontade. Somente a vontade poderia dominar a natureza falível do homem. Mas esta atividade (educação) não se origina no homem; ela tem suas regras estabelecidas nas Santas Escrituras e seu êxito está sempre ligado à graça da providência. Não há 
criação independente da ação humana, mas esta não é, senão, um meio pelo qual a verdade e o ideal de bem devem formar/ reformar a natureza corrompida do homem.

$\mathrm{O}$ que se percebe, portanto, é que durante quase mil anos (do século IV a. C. ao século XVI) a tradição platônica foi a que concebeu a educação como atividade através da qual uma determinada potência é atualizada, uma essência é realizada no homem, enquanto que subordina o homem e a própria educação a um dado ideal, apriorístico, imutável e universal, conveniente a uma sociedade cindida, desigual, verticalmente estratificada e assentada no trabalho escravo e servil.

\section{2) A pedagogia da natureza}

Ao longo dos séculos XVI e XVII, uma nova orientação educativa manifestou-se na filosofia utilizando-se da noção de natureza. Embora retomando antigas tradições, particularmente as estóicas ${ }^{3}$, mas dosando-as com as modernas ciências da natureza, fez grandes progressos no sentido de uma concepção laica e científica das leis da natureza. O intuito desses trabalhos era alcançar uma compreensão da natureza que permitisse definir as bases da vida dos homens nas relações entre si, bem como da atividade humana em todos os seus domínios. Em nome dessas bases (a natureza), podiam formular juízos sobre as instituições concretas, distinguindo o que no homem, e no mundo que o cerca, é digno de ser conservado e o que é contra a natureza, devendo ser eliminado.

Assim, a função desempenhada pelo sistema das ideias de Platão foi retomada pela noção de natureza, que se tornou lei e modelo supremos, com a diferença de que a realidade empírica do homem e do que o rodeia não era posta em dúvida, ao contrário, poderia contribuir para analisar, diferenciar, ajuizar e corrigir. A natureza torna-se, dessa forma, um sistema de ideias e normas 
com um significado geral e permanente. Consequentemente, em relação a esse sistema, a educação tornou-se dependente.

João Amós Coménio (1593-1670) foi precisamente o criador desse sistema pedagógico, através do qual ele defende que a educação deve formar o homem de acordo com uma finalidade previamente estabelecida, o que faz da ideia de natureza aí postulada, a verdadeira essência do homem. Porém a natureza para Coménio não tinha um caráter empírico, no sentido em que se considera o homem tal como ele é concretamente. $\mathrm{Na}$ Didática Magna, ele afirma que: "por natureza, entendemos, não a corrupção que, depois da queda a todos atingiu (e por causa da qual somos chamados, por natureza, filhos da ira, incapazes por nós próprios, de pensar seja o que for de bom) ... mas o nosso estado primitivo e fundamental, ao qual devemos regressar como nosso princípio" (COMÉNIO, 1996, p.101)

Deste modo, embora a natureza exista como dimensão empírica e sensível ao homem, não pode desenvolve-se completamente, já que se encontra corrompida; o homem não é homem enquanto não aprende a agir como homem - essa é justamente a tarefa da educação para Coménio.

(...) a natureza dá as sementes do saber, da honestidade e da religião, mas não dá propriamente o saber, a virtude e a religião; estas adquirem-se orando, aprendendo, agindo. Por isso, e não sem razão, alguém definiu o homem como animal educável, pois não pode tornar-se homem a não ser que se eduque... Ninguém acredite, portanto, que o homem pode verdadeiramente ser homem, a não ser aquele que aprendeu a agir como homem, isto é, aquele que foi formado naquelas virtudes que fazem o homem (COMÉNIO, 1996, p.119-120).

Substituindo a noção de ideia pela de natureza, Coménio elabora uma concepção de educação que tem como finalidade 
contribuir para que a verdadeira essência possa assenhorar-se dos homens concretos, desconsiderando o indivíduo empírico, posto que sua vida é uma vida de pecado e corrupção. Trata-se, portanto, de reconduzir o homem à sua essência mais profunda e isso deveria ser realizado por meio da formação de hábitos (ordem e disciplina), de valores, com profundo desempenho da vontade guiada pela razão e pelo bom senso.

Quanto a este último aspecto, outro autor que elaborou importantes contribuições para a filosofia da educação em consonância com esta fonte de reflexões constitutivas da "Pedagogia da Natureza" foi John Locke.

Filho de burgueses comerciantes, Locke nasceu na Inglaterra, formou-se em medicina e ocupou diversos cargos políticos. Foi um grande contestador do absolutismo, lutou pelas causas da tolerância religiosa e pelo estabelecimento de um Estado democrático, representando os interesses da burguesia nascente pela participação e ocupação do poder político.

O empirismo inglês deve a Locke suas maiores sistematizações. Reagindo contra uma mentalidade metafísica, tradicional, cristã e dogmática, elabora uma teoria cuja tese central repousa no descrédito da verdade absoluta e definitiva, imposta por uma força imaterial. Ele acreditava que o conhecimento só poderia ser adquirido mediante a experiência, pois tem nos fatos, não no homem e menos ainda na inspiração divina, a fonte de tal explicação. Com isso, vai abrindo espaço para uma discussão que começa a negar a existência de uma ordem imutável e universal, enquanto introduz uma espécie de operacionalização do conhecimento, em que a verdade torna-se aquilo que importa, que é útil, prático, que funciona bem e que não apresenta problemas.

Consoante às suas ideias sobre a operacionalidade do conhecimento e frente à necessidade de transformar os hábitos, os valores e a mentalidade da burguesia ascendente - classe da qual 
ele fazia parte - em relação às mudanças político-econômicas do período, Locke elabora uma teoria "pedagógica" que busca desenvolver nos homens, desde muito cedo, certos padrões de comportamento e ação que correspondam às expectativas de uma nova sociedade. Um ideal educativo humanista, naturalista e universalizante, de caráter integral, funcional, utilitário e nitidamente classista (Enguita, in Locke, Pensamientos sobre la educación, 1986).

Dentro de uma visão individualista de vida e de felicidade, Locke (1986) joga para o sujeito a responsabilidade pelo seu sucesso ou fracasso. É assim, pois, que a educação torna-se a esfera que cria as diferenças, ou seja, as pessoas se tornam boas ou más por conta da educação; é ela quem dá forma à personalidade do indivíduo, configurando seu caráter e sua moral. Entendida como tabula rasa, como um ser que nasce vazio e que precisa ser preenchido, através da educação, a criança poderia ser levada a qualquer finalidade para a qual se estabeleça. "Imagino que el espíritu de los ninõs toma éste ou aquél camino tal fácilmente como el agua" (Locke, 1986, p. 32).

Ao mesmo tempo, visto ter como preocupação central a formação da sociedade política, com a qual todos deviam colaborar e se integrar ${ }^{4}$, Locke advoga uma sólida formação de hábitos e costumes, para que os homens adquiram uma conduta ética, digna e moral em benefício do Estado. Seu método, a disciplina e a severidade. Seu objetivo, a organização e manutenção de uma sociedade harmônica, em que a vida, a liberdade, a propriedade e a prosperidade sejam preservadas como um organismo que se autogoverna.

Nesse sentido, o autor elabora um manual educativo para a formação do gentleman, o jovem burguês que ocuparia os cargos públicos e de administração do Estado, tão logo a burguesia assumisse o poder político na sociedade. Professando uma educação integrada, sugere que a educação do corpo e a 
aquisição de hábitos corporais são tão necessárias quanto a formação do espírito. "El que no dirige su espíritu sabiamente, no tomará nunca el camino derecho, y aquél cuyo cuerpo sea enfermizo y débil, nunca podrá avanzar por ello" (Locke, 1986, p.31).

Dentro desta perspectiva, faz uma série de considerações a respeito da saúde do corpo, da prática de exercícios físicos como a natação e a dança, da exposição das crianças ao ar livre, das vestimentas, da alimentação, do sono, da prisão de ventre e das instruções que figuram como elementos constitutivos de uma sólida formação moral voltada à educação do cavalheiro, sobretudo dos meninos. Nesse particular, apresenta uma visão de educação diferenciada conforme o sexo, reproduzindo uma concepção eminentemente sexista diante da educação de meninas.

Para que as regras mais adequadas e as normas de convivência sejam incorporadas pelo jovem ao longo de sua vida, com vistas à conquista da autonomia para guiar-se e dirigir-se em relação a elas, somente o exercício diário dos bons costumes e dos hábitos estabelecidos poderia garantir aos pais a segurança em relação à educação de seus filhos. "Porque, por más que se hagan sonar incesantemente en sus oídos las reglas y las máximas, no hay que esperar fruto alguno, ni en ningún outro caso, hasta que la práctica las haya convertido en hábitos" (Locke, 1986, p.44).

Outro elemento fundamental na formulação pedagógica de Locke diz respeito à retidão de espírito. Para ele é necessário dar à criança uma formação de caráter e de espírito capaz de colocá-la sempre à disposição de não aceitar nada que não esteja conforme a dignidade e excelência de uma criatura racional. $\mathrm{O}$ princípio de toda virtude está em poder negar, a si mesmo, seus próprios desejos, quando a razão assim autorizar. Trata-se de disciplinar a vontade, de forma a agir conforme o uso adequado do entendimento, bem como pensava Descartes ${ }^{5}$. 
Segundo os argumentos de Locke, um homem que não tem domínio de suas inclinações e impulsos, que não sabe resistir ao prazer e ao deleite, que não possui a verdadeira virtude e prudência, não pode ser um homem bom para nada. A negação do desejo pela razão, a disciplina e a formação de hábitos constituem princípios que devem ser tomados como parâmetros de felicidade e bem viver.

Como la fortaleza del cuerpo consiste principalmente en ser capaz de resistir la fadiga, lo mismo ocurre com la del espíritu. Y el gran principio o fundamento de toda la virtud y mérito estriba en esto, en que un hombre sea capaz de rehusarse la satisfacción de sus propios deseos, de contrariar sus propias inclinaciones y seguir solamente lo que su razón le dicta como lo mejor, aunque el apetito le incline en outro sentido (Locke, 1986, p.66).

A preocupação com uma educação que correspondesse ao ideário burguês o levou a estruturar um método em que, a despeito da beleza, da bondade, da força, da justiça e da coragem - virtudes centrais na formação humana desde a Paidéia Grega -, a principal preocupação se voltasse à prudência, ao equilíbrio, à retidão de espírito, à disposição corporal e à astúcia, qualidades necessárias à formação dos homens de negócio. Eis a proposta de Locke, que os desejos e instintos naturais sejam dominados constantemente pela razão, mediante um processo de disciplinarização da vontade e dos impulsos, tendo em vista os benefícios e resultados práticos e úteis de sua ação na sociedade de contrato.

Trata-se de uma posição liberal e aristocrática que expressa os anseios e interesses das classes dominantes, as quais crêem sempre que a formação do homem é tão mais perfeita entre os seus pares, do que entre os membros de outras classes sociais. 
Rousseau e a inversão da pedagogia da natureza

$\mathrm{O}$ avanço do conhecimento sobre a natureza, sobre a própria possibilidade do conhecimento e sobre o homem ao longo do século XVII permitiu que variados resultados fossem obtidos, ora salientando a bondade inata da natureza, ou o seu caráter egoísta e feroz (tal como pensava Hobbes).

Assim, se podemos considerar o homem como sendo bom, por natureza, a educação não deve ser conduzida de modo a destruir todo o seu "eu empírico" tendo em vista o renascer de sua verdadeira essência oculta; a educação poderia apoiarse sobre a dimensão empírica do homem, acompanhando o desenvolvimento de suas forças, dos seus gostos e aspirações. Se o homem é naturalmente bom, a educação não deve ir contra o homem para formar o homem. Esta é a proposta de JeanJacques Rousseau.

$\mathrm{Na}$ introdução ao Emílio ou da Educação, Rousseau polemiza com seus antecessores dizendo que: "não se conhece a infância: com as falsas idéias que dela temos, quanto mais longe vamos, mais nos extraviamos. Os mais sábios apegamse ao que importa que saibam os homens, sem considerar que as crianças se acham em estado de aprender. Eles procuram sempre o homem na criança, sem pensar no que esta é, antes de ser homem" (ROUSSEAU, 1992, p.06).

Dessa forma, diferentemente de Coménio, que toma a noção de natureza como elemento central de sua pedagogia, Rousseau a vê de um modo puramente empírico, professando o seu livre desenvolvimento, distante das amarras impositivas de uma essência determinante. Rousseau reclama o direito à liberdade, longe dos entraves da autoridade assentada na opinião, nos modelos e na moral tradicional aristocrática. Toda a proposta de Emílio é, na verdade, uma revolta contra a proposta pedagógica de Locke para a formação do gentleman - isto é, das pessoas 
bem educadas. Com efeito,

(...) se tudo é certo em saindo das mãos do Autor das coisas, tudo degenera nas mãos do homem.... No estado em que já se encontram as coisas, um homem abandonado a si mesmo, desde o nascimento, entre os demais, seria o mais desfigurado de todos. Os preconceitos, a autoridade, a necessidade, o exemplo, todas as instituições sociais em que nos achamos submersos abafariam nele a natureza e nada poriam no lugar dela.... Nascemos fracos, precisamos de força; nascemos desprovidos de tudo, temos necessidade de assistência; nascemos estúpidos, precisamos de juízo. Tudo o que não temos ao nascer, e de que precisamos adultos, é-nos dados pela educação (ROUSSEAU, 1992, p.9-10).

Com estas palavras, Rousseau anuncia sua proposta pedagógica, a de garantir o desenvolvimento livre e espontâneo do indivíduo/cidadão, posto que a educação não deve ser uma preparação da criança, de fora para dentro, para modelá-la com vistas ao seu ajustamento na sociedade; a educação deve ser a própria vida da criança, pois que a criança é a própria fonte da educação. É a partir do seu desenvolvimento concreto, de suas necessidades e dos seus impulsos, dos seus sentimentos e dos seus pensamentos, que se forma o que há de vir a ser. Em síntese, a educação é um processo pelo qual a criança se transforma naquilo que é e vive aquilo em que se transformou. Contudo, é bom que se diga, que se trata de formar um tipo próprio de cidadão, cujo papel é cumprir seus deveres de cidadão legítimo de um sociedade perfeita, idêntica à que o autor concebe no Contrato Social, bem como de uma sociedade que ainda precisa melhorar. A civilidade resulta, assim, da ação pedagógica que desenvolve as individualidades em todo o seu potencial humano, 
criando interdependência entre o conhecimento de si, de sua sensibilidade, dos atributos naturais, da compreensão e respeito ao outro, de forma a capacitá-lo para viver coletivamente em harmonia com seus semelhantes.

\section{3) $O$ idealismo de Kant}

Kant pretendia vencer ao mesmo tempo o dogmatismo tradicional e o ceticismo, propondo com isso defender a certeza e a objetividade do conhecimento humano que os empiristas, como Locke e Hume, haviam posto em dúvida, sem contudo voltar ao idealismo ingênuo ou a posições dogmáticas. Na medida em que atribui a origem do conhecimento às leis do espírito absoluto, confere a este um valor universal, ainda que limitado aos fenômenos empíricos apreendidos pelo espírito humano. Recorre, assim, à lei moral fundamental, que deveria ser obrigatória para todos, muito embora só pudesse interferir na conduta do homem no mundo empírico e não possuísse qualquer outro ponto de apoio.

Com base nessa filosofia, o problema da educação do homem tomou como modelo a própria criação humana e o mundo que apreendia. Porém, essa criação era realizada de acordo com as leis inflexíveis e universais da razão, não sendo idêntica nem à diversidade empírica dos homens, nem a arbitrariedade de sua atividade. Assim, o conhecimento e a conduta humana tinham um valor objetivo na medida em que se impunham a cada indivíduo como necessidade e dever.

Em seu texto intitulado Sobre a pedagogia, Kant desdobra as conseqüências de sua filosofia pondo em evidência a atividade da criança no domínio intelectual e moral, assim como o seu acatamento dos princípios que se impõem a todos. Para o autor, o homem é a única criatura que precisa ser educada e esta educação compreende o cuidado com a sua conservação, a 
disciplina e a instrução.

De um lado, a espécie humana é obrigada a extrair de si mesma, com a força da razão, todas as qualidades naturais que pertencem à humanidade. A disciplina é o que permite ao homem não desviar-se de seu destino, não desviar-se da humanidade. "Ela deve, por exemplo, contê-lo, de modo que não se lance ao perigo como um animal feroz, ou como um estúpido" (KANT, 1996, p.12). Assim, a disciplina tem um caráter negativo na medida em que tira do homem a sua selvageria. Já a instrução é a parte positiva da educação, pois lhe acrescenta os conteúdos da cultura. Como diz o autor, "quem não tem cultura de nenhuma espécie é um bruto; quem não tem disciplina é um selvagem" (idem, p.16)

É entusiasmante pensar que a natureza humana será sempre melhor desenvolvida e aprimorada pela educação, e que é possível chegar a dar aquela forma que em verdade convém à humanidade. Isto abre a perspectiva para uma futura felicidade da espécie humana" (KANT, 1996, p.17).

Desse modo, Kant concebe que o homem possui disposições naturais que a educação modela, já que o indivíduo não pode cumprir por si só esta destinação. Por isso é preciso acostumá-lo a submeter-se aos preceitos da razão (e não da vontade, como preconiza a versão cristã do idealismo platônico). E esta razão indica que o homem deve ser educado conforme os seguintes critérios: ser disciplinado, pois a disciplina consiste em domar a selvageria; tornar-se culto, pois a cultura é a criação de habilidade e esta é a posse de uma capacidade condizente com todos os fins que almejamos; ser prudente, para que permaneça em seu lugar na sociedade e seja querido e tenha influência. Essa prudência é um item central da civilidade, que requer certos modos corteses, regula o nosso gosto e educa para a gentileza 
em relação aos outros homens; cuidar da moralização, pois não basta que o homem seja capaz de alcançar toda sorte de fins, convém que ele desenvolva a disposição de escolher apenas os bons fins. E bons são aqueles fins aprovados por todos e que podem ser, ao mesmo tempo, fins de cada um; enfim, o homem deve ser, pela educação, verdadeiramente ilustrado.

Para Kant, a educação deve, portanto, educar a verdadeira finalidade da existência humana: agir para e com o bem, buscando a felicidade; ensinar a usar bem a sua liberdade, bastando-se a si mesmo, donde a formação do caráter e da civilidade prepara o homem culto, e a cultura é justamente o que consiste no exercício das forças da índole. Em síntese, por meio da obediência, da disciplina, do respeito aos preceitos morais, da instrução, do bom uso da razão, da avaliação diária da conduta e da formação do caráter, a proposta pedagógica de Kant é transformar o selvagem em homem, a despeito da desigualdade social que deriva das situações concretas nas quais os homens estão submetidos, bastando para isso, na visão do autor, que se inspire aos poucos, na educação dos jovens, a consciência da igualdade na desigualdade da ordem civil.

\section{4) O existencialismo de Nietzsche}

No século XIX começam a ser esboçadas as filosofias da existência que se revoltam contra os preceitos morais estabelecidos, exigindo a liberdade no sentido de viver acima do bem e do mal, do verdadeiro e do falso. Nietzsche foi o grande inspirador desse movimento, contestador das tendências massificadoras do ensino de sua época e um crítico da ordem, do poder e da moral então em vigor. Para este autor, o bem e a verdade são uma barreira erguida pelos fracos contra a audácia dos fortes. Seguindo esta premissa, ele defende um ideal de escolas-santuários destinadas à formação dos gênios, 
ou super-homens, nas quais seria ensinada uma ciência alegre e profunda, livre de qualquer relação com a verdade ou com a moral humanista de sua época.

Para o que nos interessa neste momento, cabe explorar um pouco a crítica da redução da cultura proposta por Nietzsche. Em suas "conferências" sobre o tema da educação, o autor se refere à redução da cultura como um processo de enfraquecimento, ou ainda de esvaziamento da cultura, ao passo que esta se afasta do cultivo da arte, das grandes obras, dos seus verdadeiros problemas - que são os problemas da existência -, da cultura clássica e da filosofia, tornando-se uma pseudocultura atrelada a interesses extrínsecos a ela. Esta tendência "exige que a cultura abandone as suas ambições mais elevadas, mais nobres, mais sublimes, e que se ponha humildemente a serviço não importa de que outra forma de vida, do Estado, por exemplo" (Nietzsche, 2004, p.61).

$\mathrm{O}$ que ele concebe como "autêntica cultura" parece, então, abalada por um movimento de instrumentalização e vulgarização do conhecimento, na medida em que ela é fragmentada pela expansão, diversificação e especialização da ciência, e banalizada por veículos produtores de informações vazias e sem importância para a vida e para a formação humana. Nietzsche censura, assim, a erudição e o jornalismo por serem eles os exemplos mais expressivos de como a cultura criada e cultivada na modernidade é reduzida ao comodismo de uma disciplina especializada e à mediocridade de uma linguagem bárbara. O erudito seria aquele que, "se na sua especialidade ele está acima do vulgus, para tudo mais, quer dizer, para tudo que é importante, não se mostra diferente deste" (Nietzsche, 2004, p.64). O jornal, por sua vez, "substitui a cultura, e quem ainda, a título de erudito, tem pretensões à cultura, este se apóia habitualmente nesta trama de cola viscosa que cimenta as juntas de todas as formas de vida, de todas as classes sociais, de todas 
as artes, de todas as ciências" (Nietzsche, 2004, p.65).

Articula-se, a esta crítica de Nietzsche à redução da cultura, a da extensão da cultura, segundo a qual a cultura deveria ser estendida a círculos cada vez mais amplos da população, porém assimilada como um bem utilitário, decorrente das necessidades de produção e acumulação e das carências prático-imediatas. A ampliação máxima da cultura, segundo o autor, estaria relacionada com a autopromoção, o ganho e o lucro, podendo ser definida como:

(...) o discernimento graças ao qual alguém se mantém no cume de sua época, graças ao qual se conhece todos os caminhos que permitem mais facilmente ganhar dinheiro, graças ao qual se possui todos os meios pelos quais se dá o comércio entre os homens e os povos. [...] A união da inteligência e da propriedade, que se coloca como princípio nesta concepção do mundo, toma o valor de uma exigência moral (Nietzsche, 2004, p.61-62).

Ao lado do exame da educação desenvolvida nos estabelecimentos de ensino da Alemanha naquela época, o filósofo tece duras críticas ao Estado, diga-se liberal-burguês, que colocava tanto a formação realizada nos ginásios e nas universidades, como a ação dos professores e profissionais, à serviço dos seus interesses. Através dos ginásios, o Estado fez com que nações inteiras (como é o caso da Prússia) assimilassem uma cultura uniformizada, com a qual ele obtém seu próprio reconhecimento. Nietzsche (2004) a ele se refere assim:

(...) o Estado aparece como um mistagogo da cultura e, ao mesmo tempo em que persegue seus próprios fins, ele obriga a todos os seus servidores a só se apresentarem diante dele munidos da luz da cultura universal do Estado: sob esta luz turva, eles devem reconhecer nele 
o objetivo supremo, como aquele que recompensa todos os seus esforços na direção da cultura (p.98).

Nietzsche via no ensino público tão somente o desenvolvimento de uma cultura conformista, ou para usar uma expressão tipicamente sua, uma "cultura rápida", capaz de propiciar apenas uma ilusão de contentamento ou felicidade. Aqui a idéia de alienação poderia ser evocada quando o autor estabelece uma comparação entre o erudito e o operário de fábrica, indicando que os mesmos processos de estranhamento, conformação e banalização, promovidos pela cultura escolar, permeiam ambas as condições sócio-profissionais. Além disso, entende que a cultura atrelada aos anseios capitalísticos, utilitários e produtivistas do trabalho, enfraquecem a força, o rigor, a beleza e a superioridade da cultura autêntica.

Para Nietzsche, entretanto, trata-se de uma noção de cultura e de formação humana radicada num espírito elitista e aristocrático, descrente de que as massas possam adquiri-las, até por que o acesso à verdadeira cultura, à cultura filosófica, não se dá por meio da erudição, nem da subserviência ao Estado, ao mercado, ou movido por compromissos profissionais; ela é uma dádiva que a natureza reservou a um pequeno número de indivíduos selecionados, está para além do mundo das necessidades e da existência. Do ponto de vista da educação, isto significaria romper com o imediatismo e a superficialidade da formação, reanimando os vínculos da cultura com a natureza para um cultivo aprimorado de si mesmo, engajando-se na luta individual pela vida.

Por outro lado, Nietzsche exprime uma concepção estática, inatista e quase positivista de natureza, ao passo que admite a existência natural de dois grupos de indivíduos: há um pequeno número de homens predispostos por natureza a tomar parte da verdadeira cultura, são indivíduos excepcionais, cultivados e 
aptos a criar as grandes obras que ficarão de herança à elevação e perpetuação da cultura, são os homens capazes de governar e guiar a humanidade em seu destino, isto é, o super homem ou gênio; o outro grupo compreende as grandes massas, são os indivíduos movidos pelas necessidades práticas e pelo trabalho, são os homens dominados pelo mito, pela religião, pelas crenças e pela mediocridade. A este último grupo, a verdadeira educação não poderia jamais ser concedida, pois a eles não foi dada a vocação para apreciar as grandes obras, nem a capacidade e a disciplina para desfrutar da liberdade que a natureza guardou para cada um, pois isso seria "subverter a ordem sagrada do reino do intelecto, ou seja, a vocação da massa para servir, sua obediência submissa, seu instinto de fidelidade em servir sob o cetro do gênio" (Nietzsche, 2004, p.89).

Fundamentado nestas razões, Nietzsche evoca a concentração e o estreitamento da cultura contra o processo de expansão ou democratização dos sistemas de ensino, pois a extensão da cultura a enfraquece e abala a sua natureza nobre e aristocrática. Nesse aspecto, não se desconsidera aqui que, em função de seu pertencimento à aristocracia alemã do século XIX, Nietzsche é reagente às ações e movimentos políticosociais que consolidaram a hegemonia burguesa e seu projeto político-cultural, no qual a universalização do ensino era uma condição básica, como já foi dito. Por outro lado, adverte-se para o fato de que o pensamento pedagógico de Nietzsche reforça o caráter hierárquico e antidemocrático da escola, uma vez que a verdadeira educação, para ele, é destinada apenas a um grupo seleto de super-homens.

\section{5) A síntese entre essência e existência e a filosofia da práxis}

Bogdan Suchodolski (1984) sustenta uma tese que me parece 
muito interessante para realizarmos uma análise de conjunto dessas correntes filosóficas e fontes do pensamento pedagógico ocidental. Ele diz que, no processo de desenvolvimento do pensamento pedagógico, evidencia-se uma luta crescente que ocorre entre o que se pode designar por pedagogia da essência e pedagogia da existência. A primeira atribui à educação a função de realizar no homem aquilo que ele dever ser, sendo este "dever ser" sempre determinado por uma essência. Nesse sentido, como essência, podemos considerar tanto a noção de ideia em Platão, como o deus para os cristãos, a natureza em Coménio ou a razão de Kant. O que importa é a pergunta: como deve ser o homem e para que ou com base em que devemos formá-lo? Já a segunda corrente atribui à educação a função de realizar no homem tudo aquilo que ele é em sua existência concreta. Assim, trata-se de combater tudo o que se opõe ao homem e desenvolver tudo que lhe é próprio, tal como sugere a leitura de Emílio de Rousseau ou ainda a proposta de Nietzsche para a formação do super-homem.

O problema que se coloca é que entre uma e outra corrente, o que se obtém são formulações que conferem à educação a tarefa de ajustar, adaptar ou conformar o homem de acordo com as necessidades sociais e os interesses políticos e econômicos das classes dominantes nos diferentes contextos, ou ainda compensar, restituir e mistificar a ordem social estabelecida, satisfazendo as aspirações individuais de pequenos grupos, sem, contudo, transformar as condições de desigualdade e exploração existentes. Segundo Suchodolski (1984), enquanto uma reduz o homem a receptáculo e veículo de valores culturais (pedagogia da essência), a outra o concebe como uma experiência contemplativa ou fonte de emoção mítica (pedagogia da existência). Em ambos os casos, a educação acaba por incidir sobre um domínio limitado da vida humana, sem estabelecer qualquer relação com a atividade real, concreta 
e social do conjunto dos homens ou mesmo com a totalidade da vida individual.

As contradições reais criadas nas sociedades burguesas desde o Século XVIII, caracterizadas por uma oposição cada vez mais acirrada entre existência humana e o seu ideal, não são evidentemente atenuadas por nenhuma destas correntes. Segundo penso, a única filosofia capaz de superar, de forma dialética, esse conflito, é a filosofia da práxis de Marx e Engels.

Encontramos no pensamento desses autores uma pedagogia indissociável da prática social que transforma a realidade e tende a criar no homem as condições necessárias para que sua existência seja fonte e matéria prima de sua essência. No domínio da educação, a tarefa mais importante consiste em articular as questões da vida social, determinadas pelo trabalho (em sua dimensão ontológica e histórica), à vida cotidiana e concreta do homem. Consiste em fornecer uma formação crítica que liberte os homens das ilusões, mostrando-lhe as raízes sociais das mesmas, enquanto que o estimula a uma ação para modificar a realidade que o cerca. Portanto, a consciência filosófica da práxis ${ }^{6}$ seria a arma dos trabalhadores na luta pela emancipação humana.

Dito isto, percebemos que a concepção de educação aí aludida é inseparável da luta pela emancipação humana e, nas condições atuais, pela superação do sistema do capital ${ }^{7}$. De um lado, trata-se da formação da consciência do novo homem, de outro, a construção de uma nova ordem social, ambas ligadas necessariamente à produção da vida material.

Em outras palavras, a educação está estreitamente ligada ao processo histórico da atividade social e produtiva do homem. Assim, se o trabalho humano cria e transforma o meio ambiente no qual o homem vive - expressando-se nos produtos, objetos e conteúdos da cultura material -, produz e desenvolve, ao mesmo tempo, o próprio homem. Nesse processo, o homem 
educa-se e humaniza-se ao dominar cada vez mais a natureza, no sentido de que ele dela se apropria (como primeira fonte de riqueza), de acordo com suas necessidades de sobrevivência e desenvolvimento. A partir daí ele constrói conhecimentos que se acumulam historicamente, produzindo todo um universo de símbolos, saberes, valores, comportamentos que constituem o plano de cultura não material, e que se transforma em uma segunda natureza do homem.

Esta idéia diferencia-se das concepções naturalistas e psicologistas da educação que tem como fundamento a natureza humana configurada de modo determinado e que funciona sempre como ponto de equilíbrio entre o que se é e o que se deseja ser. Ao contrário, para Marx e Engels o homem não tem uma determinação natural, posto que ele é expressão das relações sociais em seu conjunto. O indivíduo e seu desenvolvimento são concebidos segundo as tarefas históricas da classe social a que pertence e não de acordo com uma situação individual ou física.

Portanto, uma educação comprometida com a emancipação social e superação do sistema do capital deve ter como base a participação do indivíduo no movimento da história e não apenas nas divergências ideológicas, o que supõe a contribuição da educação para o fortalecimento da luta da classe trabalhadora, na medida em que esta toma consciência de sua condição no processo mesmo de sua experiência e organização.

No pensamento de Marx e Engels, por educação devemos entender três processos simultâneos e articulados entre si: educação intelectual, corporal e politécnica, uma combinação de educação e trabalho produtivo, que ainda sob a vigência do capitalismo, deve se desenvolver como educação integral, pública, gratuita, financiada pelo Estado, mas confiada aos educadores e conselhos, portanto aos próprios trabalhadores. Porém, essa educação deve ter em seu horizonte a eliminação da propriedade privada e a gestão coletiva da produção, pois 
somente com a realização de um trabalho cada vez mais criativo e significativo para o homem, com a organização cooperativa da produção e a restituição do mundo humano ao próprio homem, que a educação pode então contribuir para a formação de homens completos, cujas faculdades e capacidades se desenvolvam em todos os sentidos, permitindo, assim, a criação de verdadeiras singularidades.

A eliminação da propriedade privada constitui, portanto, a emancipação total de todos os sentidos e qualidades humanas. Mas só é tal emancipação porque os sobreditos sentidos e propriedades se tornaram humanos, tanto do ponto de vista subjetivo como objetivo. O olho tornou-se um olho humano, no momento em que seu objeto se transformou em objeto humano, social, criado pelo homem para o homem. [...] A necessidade ou o prazer perderam assim o caráter egoísta e a natureza perdeu a sua mera utilidade, na medida em que a sua utilização se tornou utilização humana (Marx, 1993, p.197-198).

Dessa maneira, para Marx e Engels, é pela riqueza objetivamente desenvolvida do ser humano - tarefa esta que educação realiza a partir do momento que o homem se libertar do reino da necessidade, ou seja, da condição que reduz seu trabalho e todas as suas potencialidades à produção da sua existência imediata - que se cria e cultiva e riqueza subjetiva, uma vez que os objetos só existem para o ser humano quando a sua faculdade para percebê-los existe como capacidade subjetiva, porque o significado de um objeto só vai até onde chega o sentido que lhe corresponde. De fato, se a sensibilidade humana e o caráter humano dos sentidos só se manifestam por meio da natureza humanizada, então, é papel da educação, juntamente com a abolição da propriedade privada, libertar o 
sentido aprisionado sob a grosseira necessidade prática, que lhe atribui unicamente um significado restrito. E se "a formação dos cinco sentidos é a obra de toda a história mundial anterior" (Marx, 1993, p.199), cabe à escola apoderar-se dessa história para democratizá-la como saber sistematizado, a fim de que o homem aproprie-se do seu ser omnilateral, de uma maneira omnicompreensiva, como homem total.

\section{Considerações Finais}

A socialização do conhecimento produzido pela humanidade é tarefa histórica da educação, e particularmente da escola moderna. Porém, a concepção liberal-burguesa, hegemônica hodiernamente, conformou a educação das classes trabalhadoras a uma formação unilateral, pragmática e minimalista - esvaziada de conteúdos científicos, culturais, técnicos e artísticos -, voltada à preparação de recursos humanos para o capital, nos diferentes lugares da estrutura produtiva e nas diferentes dimensões do mundo do trabalho.

A perspectiva de uma educação verdadeiramente universalista é a única capaz de unificar e mobilizar as classes que vivem de seu próprio trabalho a agir nas contradições e brechas do sistema do capital. Uma formação humana que se realiza de forma indissociável do processo de emancipação requer o protagonismo das classes trabalhadoras em lutas anticapitalistas. Para isso, os trabalhadores necessitam de ferramentas teóricopráticas, de uma educação intelectual, corporal, politécnica e política suficiente para lhes permitir interpretar a realidade e transformá-la. Eis a proposta e o desafio da filosofia da práxis, que além de possibilitar a elaboração da consciência filosófica, deve também atuar sobre a promoção e organização dos trabalhadores, como dirigentes de suas atividades e funções, em sua articulação ao desenvolvimento de uma sociedade 
emancipada.

Por isso, a defesa de uma escola unitária e integral é um princípio do qual não podemos abrir mão, posto que essa bandeira integra o conjunto das lutas sociais classistas pela garantia, conquista e ampliação de direitos, avançando trincheiras no processo de transformação social. Para a filosofia da práxis, a educação é, portanto, parte da estratégia revolucionária no século XXI, quando se torna possível, para os trabalhadores, conduzir e reinventar o seu próprio processo de formação.

\section{Notas}

* Doutora em Educação pela UNICAMP. Professora do Centro de Ciências da Educação da Universidade Federal de Santa Catarina - CED/UFSC.

${ }^{1}$ De acordo com Vernant (1998), para se viver segundo o sistema da pólis, a palavra adquire extraordinário destaque como um instrumento de poder. $\mathrm{O}$ discurso público se torna uma poderosa arma política, chave da autoridade do Estado. Assim, entre a razão e a virtude, a arte da política se torna um exercício de linguagem, que permite à razão tomar consciência de si mesma, de suas regras e de sua eficácia.

${ }^{2}$ A tradição católico-tomista foi fortemente influente no projeto educacional desenvolvida em nosso país durante quase três séculos pelos padres jesuítas. ${ }^{3} \mathrm{O}$ estoicismo foi um movimento que nasceu junto ao declínio da República Ateniense. Descrente dos deuses e da polis, os estóicos se voltam sobre si mesmo, para o seu mundo interior. É uma doutrina extremamente individualista, que exalta a igualdade humana pela razão e preconiza um cidadão universal sem família, sem pátria, sem obrigações, que busca sozinho, por meio de uma autonomia individual, atingir a sabedoria (NUNES, 1989). ${ }^{4}$ Para Locke (2005), são por razões práticas e úteis ao usufruto seguro de seus bens e de sua vida que os homens se unem em sociedade e abandonam o "estado de natureza". Essa associação é o meio pelo qual os homens se organizam socialmente, submetendo-se a um governo que estabelece leis conhecidas e aceitas mediante o consentimento comum. Como em Hobbes, a sociedade política é, ao contrário do "estado de natureza", resultado de um pacto social estabelecido pelo consenso, em que os homens abdicam de seus 
direitos naturais em nome da constituição e manutenção de uma determinada ordem social.

${ }^{5}$ Para Descartes (2000), o entendimento e vontade são dois elementos que se complementam e ao mesmo tempo se conflituam na construção do conhecimento. O primeiro por que é finito, embora forneça com clareza e distinção as idéias e a noção das coisas. $\mathrm{O}$ segundo porque é infinito e bem mais amplo que o primeiro. Assim, como implicação dessa prerrogativa, o conhecimento sobre a verdade e, por assim dizer, a educação, convertem-se em disciplina da vontade mediante o entendimento.

${ }^{6}$ Conforme alerta Vásquez (2007), há pelo menos três níveis de consciência. A consciência comum, que coincide com o ponto de vista imediato, unilateral, abstrato. Já a consciência idealista é aquela que reduz a atividade do homem à atividade do pensamento, à subjetividade, à interpretação e revelação da realidade por meio da consciência, mistificando, portanto, a atividade real, objetiva e material do homem. Já a consciência filosófica da práxis é aquela que supera - no sentido dialético de negação e incorporação - a consciência imediata e idealista, na medida em que se coloca sob o ponto de vista objetivo e científico a respeito da atividade prática do homem, aliás, que só é homem porque é ser social prático. Além disso, a consciência filosófica da práxis é concebida não só como interpretação do mundo, mas também como elemento do processo de transformação, articulando, dessa forma, o pensamento e a ação.

${ }^{7} \mathrm{O}$ sistema do capital seria, de acordo com Mészáros (2007), o regime do capital enraizado na exploração da força de trabalho, como uma ordem particular de controle "sociometabólico" que permeia todos os aspectos da sociedade e penetra todas as dimensões da vida humana, e não somente como uma ordem institucional historicamente específica do capitalismo associado à propriedade privada dos meios de produção.

\section{Referências Bibliográficas}

COMÉNIO, João Amós. Didática Magna: tratado da arte universal de ensinar tudo a todos. Introdução, notas e tradução de Joaquim Ferreira Gomes. 4.ed. Lisboa: Fundação Calouste Gulbenkian, 1996. 
DESCARTES, René. Meditações. São Paulo: Abril Cultural. Coleção Os pensadores, 2000.

JAEGER, Werner Wilhelm. Paidéia: a formação do homem grego. Tradução de Artur M. Parreira. 4.ed. São Paulo: Martins Fontes, 2001.

KANT, Immanuel. Sobre a pedagogia. Tradução de Francisco Cock Fontanella. Piracicaba: Editora da Unimep, 1996.

LOCKE, Jonh. Pensamientos sobre la educación. Madrid; Edições AKAL, 1986.

. Dois tratados sobre o governo. Tradução de Julio Fischer. São Paulo: Martins Fontes, 2005.

MARX, Karl. Manuscritos econômico-filosóficos. Tradução de Artur Morão. Lisboa: Edições 70, (1963/1964), 1993.

. Crítica ao programa da Gotha (maio de 1875). In: ANTUNES, Ricardo (org). Dialética do trabalho: escritos de Marx e Engels. $4^{\mathrm{a}}$ reimpressão. São Paulo: Expressão Popular, 2008.

MARX, Karl; ENGELS, Friedrich. A ideologia alemã. Volume I. Tradução de Conceição Jardim e Eduardo Lucio Nogueira. Lisboa: Editorial Presença; Rio de Janeiro: Martins Fontes, s/d.

MÉSZÁROS, István. O desafio e o fardo do tempo histórico. Tradução de Ana Cotrim e Vera Cotrim. São Paulo: Boitempo, 2007.

NIETZSCHE, Friedrich. Escritos sobre educação. Tradução, apresentação e notas de Noéli Correia de Melo Sobrinho. Rio de Janeiro: Editora PUC-Rio; São Paulo: Loyola, 2003.

NUNES, César Aparecido. Aprendendo filosofia. 3.ed. Campinas: Papirus, 1898. 
PLATÃO. Diálogos (O banquete; Fédon; Sofista; Político). Traduções de José Cavalcante de Souza, Jorge Paleikat e João Cruz Costa. São Paulo: Editora Abril Cultural, 1972.

ROUSSEAU, Jean-Jacques. Emílio ou Da educação. Tradução de Sérgio Milliet. Rio de Janeiro: Editora Bertrand Brasil, 1992.

SUCHODOLSKI, Bogdan. A pedagogia e as grandes correntes filosóficas. Tradução de Liliana Rombert Soeiro. 3.ed. Lisboa: Livros Horizonte, 1984.

VÁSQUEZ, Adolfo Sánchez. Filosofia da práxis. Buenos Aires: CLACSO; São Paulo: Expressão Popular, 2007.

VERNANT, Jean-Pierre. As origens do pensamento grego. Tradução de Ísis Borges B. da Fonseca. 10.ed. Rio de Janeiro: Bertrand Brasil, 1998. 